\title{
Tourism and Acculturation: A Study of Goa
}

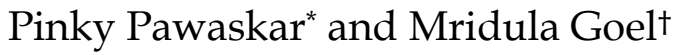

\begin{abstract}
Renowned for its beaches, places of worship and world heritage architecture, Goa is visited by large number of international and domestic tourists each year. The culture of the Goan people and their acceptability of tourists from different lands play a critical role in making this small state a popular tourist destination in India. In this paper we attempt to study how acculturation through Portuguese rule has given Goa a 'Westernized' image. The ease with which this cultural change can be exhibited in tourist products like food, music, dress, language has helped to promote cultural diffusion. It has also resulted in attitudinal change. These symbols of cultural diffusion, along with the attitude of the natives make this beautiful coastal paradise a popular destination. A warm welcome with the westernized attitude of non interference helps the tourists 'to be your-self and provides a competitive advantage to the region.
\end{abstract}

Keywords: Acculturation; Goa; cultural diffusion; westernized image.

\section{Introduction}

Tourism has become a dynamic and competitive industry that requires the ability to constantly customize so as to relate closely

* Lecturer in Management, BITS Pilani, KK Birla Goa Campus, Goa, India, pinkyp@bits-goa.ac.in

† Professor and Head of Department in Economics, BITS Pilani, KK Birla Goa Campus, Goa, India, mridula@bits-goa.ac.in, mridulamh@gmail.com 
with customer's satisfaction, safety and enjoyment. Tourism is not only expected to contribute to $12 \%$ of the world's GDP (Travel and Tourism Economic impact 2012), but it also contributes to economic diversification and profitability by increasing employment, improving basic services, and increasing economic equity between urban and rural populations (MacPherson, 1997; Narayanan, 2002; Byrd et al, 2009).

India has tremendous potential to become a major global tourist destination and the Indian tourism industry is attempting to exploit this potential. Travel and tourism industry contributed to around $6.0 \%$ to India's GDP i.e. about $\$ 67.3$ billion in 2009. By 2019, this is expected to grow to $\$ 187.3$ billion (World Travel and Tourism Council, 2009).

Goa, a tiny state on the west coast of India, known for its swaying palms, white sands and sparkling waters is one of the prime destinations of tourism in India. Tourism contributes to over 13\% of the state GDP, and is the second largest sector after mining. Goa was also listed in 'the top 10 destinations for foreign tourists', by the Tourism Ministry of India in the year 2010. Goa meets up to the expectations of the tourists by providing a warm welcome and their mentality of immediate acceptance. The attitude of the natives is an important factor in attracting tourists to this coastal haven.

\section{Culture as a Pull Factor for Tourism}

The popularity of a destination depends upon the satisfaction of the tourists with regards to the overall experience of the trip. This includes travel, food, stay, and the experiences of the overall environment in general. Host-guest interactions are an inevitable occurrence while on vacation, and tourists expect that their interaction with the host community will result in positive experiences. According to many researchers, destination communities are a basic element of modern tourism. Keogh states that (1990, cited in Costa and Ferrone, 1995) involvement and participation of the residents of a destination is important for successful tourism planning. Costa and Ferrone (1995) also sustain the same idea. They further found that the way local residents 
perceive tourists is highly influenced by their own socio-cultural background as well as by the impact of tourism on their land.

Part of a destination image includes those welcoming faces of the local community, willing to provide prompt and friendly hospitality. As said by Dunn and Dunn (2002), it is not physical structures, or even natural features that distinguish one Caribbean destination from the other, but the warmth and uniqueness of the people.

Thus, the inherent culture of a place plays a vital role in attracting tourists and is a critical attractive factor for tourism. When Tylor conceptualized culture in 1871, he saw it as "that complex whole which includes knowledge, beliefs, art, law, morals, customs and any other capabilities and habits acquired by man as a member of the society" (Charles, 2005). It is a blend of different traditions and rituals that greatly influences the food, dress, festivals, languages and the overall image of the place.

The culture of the Goan people has played a critical role in making this small beautiful state one of the most popular tourist destinations of India. The attitude and behaviour of the natives has always provided a warm welcome to the tourists and enabled them to enjoy their own lifestyle preferences while on holiday in Goa. It is to a large extent this significant attribute that positions this destination as a place to 'be your-self'.

\section{Acculturation as an Outcome of Colonization}

The cultural evolution of Goa has been the result of historical interface, due to the rule of different people in Goa, namely the Aryans, Mauryans and other Hindu rulers down to the Muslims and finally the Portuguese.

The last rulers of Goa, the Portuguese left a strong mark on Goan culture and society which to date is indelible. They ruled Goa for almost 450 years during which they adopted a social approach of converting the locals (especially the Hindus) to Christianity with a promise to safeguard and protect their future for generations to come. They kept their promise and these converts continue to benefit from Portuguese support till date. According to the 
information provided by the home department authorities in the state secretariat, nearly 1,200 Goans have acquired Portuguese passports since January 2008 to 2010. Lure of better life and huge earnings in European nations, particularly the United Kingdom, have made a considerable number of Goans acquire Portuguese passports using which they could easily travel to countries in the European Union (EU) and get employment. Being a subject of the then Portuguese government, Goans are eligible for its citizenship and hence they easily get the passports too (The Navhind Times, 2010).

These converted families have followed the Portuguese rituals and customs for years together which are now inextricably woven into the Goan social fabric. The Portuguese rule had influenced Goa to such an extent that till date Goa is known as the West of the East. It is therefore, in historical context that we find the reasons not only for the rich cultural and archaeological heritage of Goa but also, appreciate the 'Westernization' phenomenon of many of the people of this state. The Portuguese rule, thus started the process of acculturation of the Goans, developing in them a strong similarity with the Portuguese culture.

Acculturation explains (Sam, \& Berry, 2010) the process of cultural and psychological change that results following a meeting between the cultures. The effects of acculturation can be seen at multiple levels in both the interacting cultures. At the group level, acculturation often results in changes to culture, customs, and social institutions. Noticeable group level effects of acculturation often include changes in food, clothing, and language. At the individual level, differences in the way individuals acculturate have been shown to be associated not just with changes in daily behaviour, but also with numerous measures of psychological and physical well-being.

Acculturation theoretically embraces all cases of culture contact and the resulting changes in all the parties involved. It has mostly been employed in first-hand studies of the impact of a hegemonic Western culture on native cultures, as in colonialism or neocolonialism. Considering the state of the world during the rise of Western imperialism and its often profound effect on lessdeveloped people, it is easy to see why and how acculturation 
happened. Therefore, one can associate acculturation with the process of culture change that occurs when a society with superior technological sophistication comes into contact with one of the lower technological sophistication. The latter is most likely to become an acculturated society, experiencing dramatic shifts in social structure and world view.

The Portuguese rule had influenced the Goans in a similar fashion. The Portuguese wanted to develop Goa so that it can be a beautiful part of Portugal, an extension for relaxation and bliss. They knew that unless fencing of power around the land was undertaken, they would not be able to explore the wealth of the territory till eternity and if the fencing was to be of a permanent nature, it was necessary to liquidate the Indianness and local population and replace it with Portuguesism. This is the main reason why Alfonso de Albuquerque vigorously promoted marriages between the locals and the Portuguese and why any atrocities committed in the name of religion were tolerated by the Portuguese authorities as they were convinced of the fact that if along with religion, Portuguese language, literature, history, usages and customs could be thrust on the locals, this store of wealth (Goa) would come to their hand forever. The cardinal principle of this policy was that the Portuguese could enjoy the pride of the conqueror, without making the Indians feel humiliated of being conquered (Angle 2005).

The research propositions derived from the acculturation model suggest:

a) Portuguese rule promoted westernization of Goa.

b) Westernization gives a unique advantage to the people of Goa in attracting tourism pertaining to the both foreign and domestic arenas.

c) Adoption of the culture of the West is manifested easily through experimentation and exhibits good visibility of results (Lew, 1989).

The above propositions can be studied through the following graphical model 


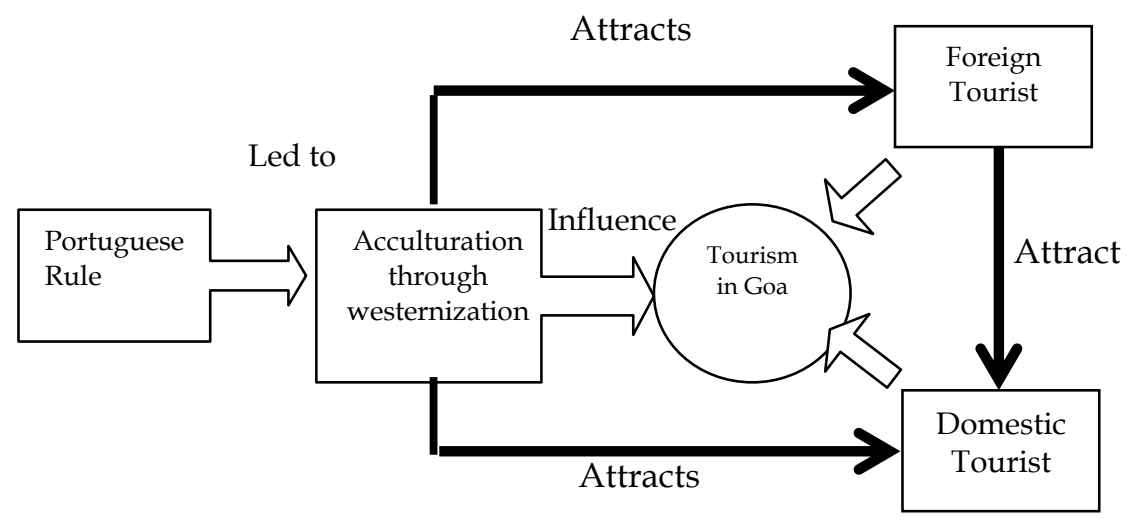

Figure 1.

\section{a) Portuguese rule promoted westernization of Goa}

Portuguese had sustained their rule in Goa ruled for a period of 450 years by the method of conversion. The Portuguese (Angle, 2005) wanted Christianization of Goa for two reasons, one, the Portuguese rulers were pure Catholics and believed that God had enjoined upon them the task of propagating the Christian religion and the second most vital reason was the principle that if one has to stabilize one's political power in an alien land, the population of this land should be of one's own religion and culture. In order to popularize the religion they had started writing Konkani in Roman scripts. They incorporated several benefits in their proposals like the locals who learnt Portuguese would hold high posts in services and could also be deported to Portugal for better prospects. Teachers at various schools would be appointed on the basis of their knowledge of Portuguese language. They set up Christian missionaries that would get people to convert into Christianity, by luring them with offers and opportunities of financial and economic prosperity. This policy of 'assimilation' adopted by the Portuguese sowed the seeds of a western culture in the Indian soil.

Mascarenhas-Keyes (1994) comments on the impact of Portuguese rule on promoting western culture in Goa which was adopted by the Catholic Goans under pressure from colonial policy and in some cases voluntarily, and is characterized by Christian first names and Portuguese surnames, dress, diet, music, education and language. The position of women changed in a number of ways, for 
instance in the late age of marriage, celibacy, entry to religious orders to become nuns and improved property rights (Wilson, 1999)

All of these seem to confirm the view that the Portuguese legacy has provided a wide range of identification with Europeans which are quite different from elsewhere in India. A number of Catholic Goans claimed that the local Hindu population has also absorbed some of these qualities and even the Anthropological Survey of India 1993 notes these differences compared to the other parts of India.

The acculturation that had taken place decades ago still seems to project itself successfully. Despite more than three decades (Crowther, Raj, Wheeler, Finlay \& Thomas 1993) since Portuguese colonial rule, Roman Catholicism remains the predominant religion, skirts outnumber saris, and the people display an easygoing tropical indulgence, humour and civility which you will find hard to beat. Even after 50 years these observations remain valid.

In the present day context, also, there are several attempts made by both Goa and Portugal to revive their ties in a mutually benefiting manner and promote their cultures. Institutions like St Xaviers College at Mapusa in North Goa along with Fundacao Oriente and Instituto Camoes, celebrate Portuguese day on August 11 as a dedication to celebration of Portuguese language and culture. Lisbon, the capital city of Portugal, recently hosted an event named Semana da Cultura Indo-Portuguese (Goa) which was a mélange of art, music, cuisine and cinema and which provided an opportunity for the Goa entrepreneurs to partner with Portuguese businessmen in the field of investment (The Times of India- Goa, August 30 2012).

The historical background of the state has played a vital role in moulding the behaviour of the locals towards other cultures. Goa is a perfect example of a state that can see acculturation with a positive lens. Percival Noronha, 80, a former bureaucrat who served both under the Portuguese and Indian administrators: states We were ruled by the Portugese for 450 years and 23 days. We were a closed shell. The result of this is that we are different from other Indians. While our ethos is Indian, there is no denying the fact that our manners, our way of thinking, is western." This is one 
possible reason why the influence of the western culture does not completely erode the Goan customs since they overlap on several accounts.

Such acculturation has increased the attractiveness of Goa as a westernized destination tolerant to foreigners from the West and attractive to domestic tourists keen to get a 'foreign-western' experience/flavour. The natives possess a non interfering attitude which appears comforting to the foreign tourists who otherwise become a centre of attention, not necessarily flattering. This is unlike the usual behaviour of the locals in other tourist destinations, especially in the developing country destinations. Thus an important explanation for the friendly welcome that most tourists experience, resides in the nature of the Goan society itself, specially, its long Portuguese association, the extensive spread of Catholicism and the Westernization of the local population.

\section{b) Westernization gives a unique advantage to the people of Goa in attracting tourism both foreign and domestic.}

Research suggests that (Agnieszka \& Małgorzata, 2010) a tourists selection of a destination is highly influenced by his/her own cultural background. The similarity and compatibility in cultures makes it easier for a tourist to feel comfortable in a new place without being hurt or embarrassed due to cultural differences.

Goa receives its highest number of foreign tourist from UK and Russia (Economic survey 2010-11-Directorate of Planning, statistics \& evaluation-government of Goa). Both these nations have a culture that is termed as reserved and individualistic. For instance (A Guide to British Culture 2009) the British are generally seen as being quite reserved and like keeping 'themselves to themselves', and are only willing to help if you specifically ask for assistance. They may not be so willing to talk to you if you ask too many personal questions. However what might seem like a normal question-Where are you from? may be considered nosey.

Terry Tan (1992) in 'Culture Shock Britain' recommends “When you get one word answers, stop asking questions, and return to the safe ice-breaking subjects such as the weather, pets, gardens, children and their antics and community welfare". But an Indian is more friendly, personal, inquisitive yet hospitable. They don't feel 
offended by asking or taking personal questions. Therefore, though being a part of India, Goans have an attitude that is likeable to foreigners, like that of non-inquisitiveness, thereby giving the visitors more personal space which makes them comfortable.

One frequent comment (Wilson, 1999) from tourists was that the Goan people were warmer and more welcoming of international tourists than they had expected and it was more so than elsewhere in India. Guidebook writers such as Turner have also noted this:

In-spite of their varying ancestry (and religious beliefs) there is undoubtedly a Goan identity of attitude, which expresses itself in a relaxed view of life and generally laid-back manner, which strangers find most appealing (Turner 1994).

The Goan Philosophy of live and let live means tolerance towards those who might be thought awkward members of stricter societies, and at the same time the young, whether hippy or not, who come to Goa . . . find there the exotic strangeness of Asia accompanied by the reassuring familiarity of those aspects of Goan life that are European in origin (Richards, 1993). Its own history and society has been highly influenced by foreigners and therefore their further interaction with other foreign cultures only makes it easy for the locals to accommodate and accept tourist behaviour.

Goa has forever been promoted as a place of fun, frolic and foreigners. The image created by promoters has given it an identity of a western zone on the eastern lands. This image has extensively popularized tourism and has placed Goa on the map of the world. The Goan beaches have always been an attraction to the domestic tourists not only for their scenic beauty but also for the foreigners who are usually seen sun-bathing for long stretches on the beaches. The Indian response (Wilson, 1999) to the semi-naked bodies on the beach has been an ambivalent one. For some, the foreign tourists have become objects of curiosity and voyeuristic interest, and there is a well established tradition of Indian tourists visiting the beaches to observe the activities of the hippies and photograph the western women. Therefore it can be sad that westernization has contributed to the growth of domestic tourism in Goa.

Goa has the highest GDP per capita amongst all the 28 states of India. Considering that travel and tourism contribute to $13 \%$ of the 
state's GDP the important role of tourism for the development of the state is unquestionable. Goa is listed on 'the top 10 destinations for foreign tourists', by the Tourism Ministry of India. During the calendar year 2010, 22,01,752 domestic and 4,41,053 foreign tourists visited the State of which $34.94 \%$ were from U.K.

Figure 2. Nationality-wise foreign tourist arrivals during the year2010

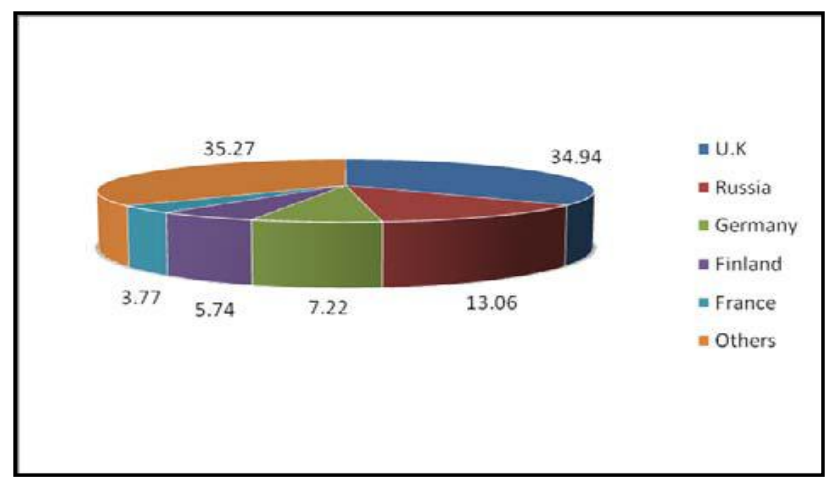

Source: Economic survey 2010-11 -Directorate of Planning, statistics \& evaluation- government of Goa

The government of Goa is also keen to encash on this unique advantage. Tourism spending as a percentage of the total state expenditure in Goa is $0.54 \%$, ranked 3rd after Sikkim $1.21 \%$ and Jammu \& Kashmir 0.59\% (State ranking Survey 2011). Thus it is apparent that the tourism advantage is well recognized by the people and the Government of Goa for the considerable economic benefits that it accrues to the state.

\section{c) Adoption of the culture of the West is manifested easily through experimentation and exhibits good visibility of results.}

Innovation, diffusion (Lew, 1989) is the process by which one social group adopts practices that were originally developed by another social group. The degree of similarity or difference between the two groups is believed to have a bearing on the degree to which one group will adopt the practices of another. Some researchers focus on the characteristics of the receiver group. Of particular interest is the receiver group's perception of the innovation in terms of 
relative advantage, compatibility, complexity, experimentation (ability to try without adopting), and visibility of results. The adoption process is an ongoing one in which decisions to keep or reject the ways of the dominant culture occurs at varying intervals and to different degrees. The phenomenon of Innovation diffusion is very mush applicable to the context of acculturation in Goa.

As discussed earlier, Goan culture has been highly influenced by Portuguese which has drawn the place towards a more westernized setting. Since the people had been exposed to western culture for a long time and they were to a great extent, accustomed to the changes that they had imbibed that is incorporating the western customs and habits into their everyday activities. Over the years tourism has attracted several international tourists to Goa due to this westernized image and they have found it to be a comfort zone due to the similarities on several accounts.

In 1990 Urry, introduced the idea of the tourist gaze. He argued that the tourism industry is constantly searching for new ways to satisfy the tourist gaze by locating, and creating, new tourism products for the tourist to experience. It is known that a destination is promoted through the products and services it offers to its customers.

Goan entertainment has been largely dominated by the English language apart from the folklore which is in Konkani. The hotels and restaurant widely flaunt English music and karaoke entertainment with western dances giving its ambience a very foreign and stylish atmosphere. Many hotels have been built on Portuguese architecture and also been given Portuguese names which is an attempt to maintain its Portuguese connections.

Food is also a cultural symbol (Edles, 2004); it is one of the cultural traits that humans first learn from childhood, and one that consumers change with the greatest reluctance at an older age (Gabaccia, 1998; Cervellon, 2005). Goa offers a wide range of cuisines which are mainly continental and more to the tastes of the foreign tourist. Its staple food fish curry and rice, however, retains a strong seat amongst the choice of dishes. As mentioned earlier Goa is visited by people from many countries and catering to their needs is necessary for building loyalty in customers. The multi- 
cuisine nature of food throughout the place helps attract foreigners and also lures the domestic crowd towards an international experience. Several places have their menu cards written in different languages like Russian and French besides of-course English for the convenience of the tourist.

The beaches, the churches, the Carnival, the music, the cuisine, and the townscape are subtly marketed in the Indian media as 'foreign' experiences on Indian soil. The luxury hotels are, of-course, luxuriously western in style, and appear in advertisements - and in reality - as western oasis in the indigenous setting. The prolonged stays and settlement of foreigners in Goa has only enhanced this image and has further helped in attracting international and domestic tourists to the state.

\section{Conclusion}

The study of tourism in Goa suggests that the process of Acculturation, specifically translated to Westernization, has gained a unique advantage to the state. The long rule and domination of Goa by the Portuguese created 'Westernization' of the natives. This helps them to attract tourists by providing a right social setting to add to the natural scenic beauty of this coastal haven.

\section{References}

Angle, P. S. (2005). Goa concepts and mis-concepts, Goa Hindu Association

Anthropological Survey of India. (1993). People of India: Goa. Bombay: Popular Prakashan.

Byrd, E. T., Bosley, H. E., \& Dronberger, M. G. (2009). Comparisons of stakeholder perceptions of tourism impacts in rural eastern North Carolina. Tourism Management, 30(5), 693-703.

Cervellon, M. C., \& Dube, L. (2005). Cultural influences in the origins of food likings and dislikes. Food Quality and Preference, 16, 455-60.

Charles, J. (2005). Social Anthropology: Concept, Theory and Ethnography. Lagos: Serenity Ventures.

Costa, Jorge and Ferrone, Livio. (1995). Sociocultural perspectives on tourism planning and development. International Journal of Contemporary Hospitality Management, 7(7), 27-35. 
Crowther, G., P. Raj, Wheeler, T., Finlay, H. and Thomas, B. (1993). India: A travel Survival Kit (5 $5^{\text {th }}$ ed) Australia: Lonely Planet.

Dunn, H. S., \& Dunn, L. L. (2002). Tourism and popular perceptions: mapping Jamaican attitudes. Social and Economic Studies, 51 (1), 25-45.

Edles, L. D. (2004). Rethinking 'race', 'ethnicity' and 'culture': Is Hawaii the 'model minority' state?. Ethnic and Racial Studies, 27(1), 37-68.

Explore series (2009). A guide to British Culture, compiled by Thinking People U.K.

Gabaccia, D.R. (1998). We Are What We Eat. Cambridge, MA: Harvard University Press.

Lew, \& Alan, A. (1989, September). Innovation diffusion and cultural adaptation: Geography and social change. Fairbanks, Alaska association of pacific coast geographers.

MacPherson, C. (1997). Measuring the economic impact of participants involved in community sporting events. (Master's thesis).

Mascarenhas-Keyes, S. (1994). Language and Diaspora: The Use of Portuguese, English and Konkani by Catholic Goan Women in Goa. In P. Burton, K. K. Dyson \& Ardener, S. (Eds.), Bilingual Women: Anthropological Approaches to second language use, (pp 149-166). Oxford, UK: Berg publications.

Narayanan, D. (2002). Impacts of tourism and demographic developments in a rural Spanish Pueblo. (Master's Thesis).

Niezgoda, Agnieszka, Bartosik, P., \& Malgorzata, P. (2010, May). The effect if culture related factors on tourist buying decisions marketing implications for tourism firms. University of Zagreb International conference, Zagreb.

Richards, J. M. (1993). Goa (revised ed). New Delhi: Vikas Publishing House.

Rudmin, F. W. (2003). Critical History of the Acculturation Psychology of Assimilation, Separation, Integration, and Marginalization, Review of General Psychology, 7(1), 3.

Sam, D. L. \& Berry, J. W. (2010). Acculturation: When Individuals and Groups of Different Cultural Backgrounds Meet. Perspectives on Psychological Science, 5(4), 472.

Thadani Manav, Tuli Megha, Karulkar Aditya. (2011). State ranking Survey - India by HVS Global Hospitality Services. 
Tan, T. (1992). Culture Shock Britain. London: Kuperard.

Travel \& tourism Economic impact- India (2009). World travel and Tourism Council, 1-2 Queen Victoria Terrace, Sovereign Court, London E1W 3HA, UK.

Turner, C. (1994). Visitors Guide, India: Goa. Ashbourne, UK: Moorland Publishing.

Urry, J. (1990). The tourist gaze. London : Sage Publications.

Wilson, D. (1999). Paradoxes of tourism in Goa Norman Dantas (Ed.): In the Transforming of Goa. Other India Press. 